\title{
Distribution, ecology and reproductive biology of wild tomatoes and related nightshades from the Atacama Desert region of northern Chile
}

\author{
Roger T. Chetelat $\cdot$ Ricardo A. Pertuzé • \\ Luis Faúndez $\cdot$ Elaine B. Graham · Carl M. Jones
}

Received: 16 September 2008/ Accepted: 8 December 2008/Published online: 25 December 2008

(C) The Author(s) 2008. This article is published with open access at Springerlink.com

\begin{abstract}
Over the past 20 years, several expeditions were made to northern Chile to collect populations of wild tomatoes (Solanum chilense, S. peruvianum) and allied nightshades (S. lycopersicoides, S. sitiens), and obtain information about their geographic distribution, ecology and reproductive biology. Restricted mainly to drainages of the Andean and the coastal cordillera, populations are geographically fragmented. The two nightshade species are rare and threatened by human activities. Adaptation to extreme aridity and soil salinity are evident in $S$. chilense and $S$. sitiens (the latter exhibits several xerophytic traits not seen in the tomatoes) and to low temperatures in S. lycopersicoides and S. chilense. All tested accessions are selfincompatible, with the exception of one S. peruvianum population collected at the southern limit of its distribution. Several distinguishing reproductive traits-anther color, attachment, and dehiscence,
\end{abstract}

R. T. Chetelat $(\bowtie) \cdot$ E. B. Graham · C. M. Jones

C. M. Rick Tomato Genetics Resource Center,

Department of Plant Sciences, University of California,

One Shields Ave., Davis, CA 95616, USA

e-mail: trchetelat@ucdavis.edu

\section{R. A. Pertuzé · L. Faúndez}

Depto. Producción Agrícola, Universidad de Chile,

Casilla 1004, Santiago, Chile

Present Address:

E. B. Graham - C. M. Jones

Seminis Vegetable Seeds, 37437 State Highway 16,

Woodland, CA 95695, USA pollen size, and flower scent-suggest $S$. sitiens and $S$. lycopersicoides attract different pollinators than $S$. chilense and $S$. peruvianum. The four Solanum spp. native or endemic to Chile provide a variety of novel traits which, through hybridization and introgression with cultivated tomato, could facilitate development of improved varieties, as well as research on a variety of basic topics, including plant-pollinator interactions, abiotic stress responses, and evolution of reproductive barriers.

Keywords Solanum sitiens .

Solanum lycopersicoides . Solanum chilense .

Solanum peruvianum . Tomato ·

Germplasm collecting

\section{Introduction}

The cultivated tomato and its wild relatives form a small clade of 13 closely related species, comprising Solanum sect. Lycopersicon, formerly recognized as the genus Lycopersicon (Peralta et al. 2008). Four other Solanum spp. are the closest outgroup species to the tomato clade: $S$. ochranthum and S. juglandifolium in Solanum sect. Juglandifolia, and S. sitiens and S. lycopersicoides in sect. Lycopersicoides.

The wild tomatoes and related nightshades are native to the Andean region of South America, 
including parts of Ecuador, Peru and Chile. In Chile, they are found only in the northernmost three administrative Regions (Arica-Parinacota, Tarapacá, and Antofagasta). They include representatives of sect. Lycopersicon, S. peruvianum, S. chilense, and of sect. Lycopersicoides, $S$. lycopersicoides and $S$. sitiens. Endemic to Chile, S. sitiens is limited to arid slopes to the NW and S of the city of Calama. Its sister species, S. lycopersicoides, is found in just a handful of steep drainages near the Peru/Chile frontier. The natural range of $S$. peruvianum is primarily in Peru, where it is widespread along the West coast and in the Andes, and extends into northern Chile. It overlaps with $S$. chilense-widespread in northern Chile but extending into southern Peru-as well as with $S$. lycopersicoides.

Prior to 1985 , relatively few ex situ accessions of wild tomatoes from Chile were available in national or international genebanks. The holdings of the C. M. Rick Tomato Genetics Resource Center at UC-Davis were limited to a few collections made by Charles M. Rick (UC-Davis) in 1957, and by Carlos Ochoa (Centro Intl. de la Papa) in 1982. During the period 1985-1988, Rick, Andres Contreras (University of Austral, Chile), Rudolf Thomann, Miguel Holle (Centro Intl. de la Papa) and their associates made several trips to northern Chile to collect wild tomatoes (Thomann et al. 1987). Sponsored by the IBPGR (International Board for Plant Genetic Resources), these expeditions benefited from favorable climatic conditions, particularly in the normally hyperarid coastal mountains, and resulted in a thorough sampling of the geographic area. Still, a number of 'gaps' in the collections remained, prompting two additional expeditions in 2001 and 2005, which were sponsored by the USDA Plant Exchange Office.

The primary objective of the 2001 trip was to collect additional populations of $S$. lycopersicoides and S. sitiens, both underrepresented in the TGRC and other ex situ collections. The natural range of each species is confined to small areas within the Atacama Desert region. Previous observations suggested some populations were threatened in situ by human-associated factors, such as grazing, mining, and other activities. The number of collections of these species was limited: for $S$. sitiens, only five populations were known, all but one of which originated from a small area around the mining town of Chuquicamata. More accessions of S. lycopersicoides had been collected, yet there remained large geographic gaps between these known populations.

The principal goal of the 2005 visit was to collect additional populations of $S$. chilense from the coastal cordillera, and to fill in gaps in existing collections of the other taxa. Our studies of genetic diversity and relationships in S. chilense (Graham 2005) had indicated that populations at the northern and southern ends of the distribution are genetically diverged and isolated by partial reproductive barriers from each other and from populations in the center of the distribution. Yet there were relatively few accessions of $S$. chilense collected from coastal sites in the TGRC or other genebanks.

Among the reasons for thoroughly collecting the available wild populations are that (a) some are threatened or have already been extirpated by overgrazing or other activities, and (b) each of these four species possesses unique traits that could lead to further improvement of the tomato crop (reviewed by Rick and Chetelat 1995). In the past, breeders have tapped $S$. chilense and $S$. peruvianum for disease resistance traits that were unavailable within the genepool of cultivated tomato. For instance, $S$. peruvianum is the source of several widely deployed $\mathrm{R}$ genes, including $\mathrm{Mi}$ for resistance to root knot nematodes (Meloidogyne spp.), Tm-2 for Tobacco Mosaic Virus resistance, and $S w-5$ for tomato spotted wilt virus (TSWV) resistance. Novel traits bred from S. chilense include resistances to TYLCV (tomato yellow leaf curl virus) and other gemini viruses, cucumber mosaic virus (CMV), TSWV, as well as fruit quality traits such as elevated antioxidant compounds. The nightshades S. lycopersicoides and $S$. sitiens possess other potentially unique characteristics not found among the Lycopersicon clade species (Rick 1988). The former is known for its broad suite of disease resistance (summarized in Chetelat et al. 1997), including Botrytis cinerea, all races of Xanthomonas campestris, Phytophthora parasitica, cucumber mosaic virus (CMV), tomato yellow leaf curl virus (TYLCV), and the tomato criniviruses TICV and ToCV (William Wintermantel, persersonal communication), as well as tolerance to low temperatures. The second nightshade, S. sitiens, has not been thoroughly tested for economic traits, but its ability to thrive in the Atacama Desert certainly indicates a high level of drought tolerance. Our tests of soil samples taken at sites where this 
species grow also indicate a high level of salt tolerance. In addition, $S$. sitiens could be a source of novel fruit textural properties-its fruit mature via a unique desiccation process, rather than the ripeningassociated softening, color, and odor changes typical of the tomatoes. Introgression lines (ILs) and similar prebreds that capture the genomes of related wild species via overlapping chromosome segments in the genetic background of cultivated tomato, are useful resources for plant breeders (Zamir 2001). A complete library of ILs for S. lycopersicoides and a partial set for $S$. sitiens have been synthesized, and should enable the transfer of economic traits in the future (Canady et al. 2005; Pertuze et al. 2003).

In the present paper we summarize and integrate our observations and results from six germplasm collecting expeditions to northern Chile. The current geographic distribution, ecology, and reproductive biology of each species are described, and their future status is discussed in relation to potential impacts from human-associated activities.

\section{Methods and materials}

Choice of geographic areas

Geographic areas likely to contain 'new', i.e., previously uncollected, wild populations were identified by consulting herbarium records, lists of flora from specific regions, GIS and other physical maps to identify habitat, and local experts familiar with the region. A database of tomato herbarium specimens collected in Chile, with locality information (sometimes with latitude and longitude coordinates), was kindly provided by Sandra Knapp (Natural History Museum in London), David Spooner (USDA Agricultural Research Service; University of Wisconsin), and Iris Peralta (University of Cuyo, Argentina). Additional herbarium specimens from the Quinta Normal herbarium in Santiago were examined for locality information. The Andean Biological Information System and the associated 'LomaFlor' database (http:// www.sacha.org/) were searched for records of tomatoes from the 'lomas' (fog-supported plant communities) of northern Chile. Using herbarium records and plant lists from various sources, we identified several sites where each of these four taxa had been found by botanists in the past. The more recent herbarium records included GIS coordinates, which allowed us to navigate to relatively remote populations. GIS-based maps of currently held accessions were studied for gaps in our existing collections, and to identify likely habitat for the tomato species, notably in the drainages of the Andes. Finally, one of the authors (LF) has conducted botanical surveys in the Atacama Desert in the past, and was familiar with the location of several previously uncollected populations. For the 2001 and 2005 trips, these sources of information were used to lay out collecting routes and itineraries that would increase our chances of finding populations not collected previously.

\section{Seed harvest and processing}

For each population, the total number of plants in the immediate area was counted or visually estimated. To the extent possible, seed were collected from all plants bearing ripe fruit. Several fruit from each plant were harvested and wrapped in tissue paper and bagged to protect them from damage and decay during transport. After 1-2 weeks, the seeds from individual fruit were extracted, blotted onto newspaper to absorb excess moisture, flattened onto sheets of paper, and dried overnight at room temperature. In this way, seed from individual fruit of each source plant could be later isolated and identified.

The several expeditions to Chile in the period 19852005 resulted in a combined total of 150 individual plant collections, consisting of 92 S. chilense, $22 S$. peruvianum, 21 S. lycopersicoides, and 15 S. sitiens accessions. Data on the individual accessions-collection site, elevation and GIS coordinates, numbers of plants sampled, etc.-are available at the TGRC website (http://tgrc.ucdavis.edu). Seed from each accession were multiplied in the greenhouse at the TGRC, and samples of most accessions are now available to interested researchers upon request. Seed samples of all accessions were backed up at the National Center for Genetic Resources Preservation in Ft. Collins, Colorado. Samples from the 2001 and 2005 collections were also deposited with the Instituto Nacional de Investigaciones Agropecuarias (INIA) in Chile. Trip reports for these two most recent trips are available at the TGRC website.

Notes on the ecology and habitat of each population site were taken at the time of collection. Associated plant taxa were listed, soil, drainage, 
exposure, and other site characteristics were noted, and any signs of damage from grazing or other activities, presence of pollinating insects, or consumption of fruit/seeds by rodents or other potential seed dispersal vectors were recorded.

Soil tests

Soil samples were collected from a number of locations in which wild tomatoes were found. Samples were taken within $30 \mathrm{~cm}$ of the plant crown of at least two plants per accession, and the soil profile to $15 \mathrm{~cm}$ deep was sampled. Several $\mathrm{kg}$ of soil were mixed in a bucket, and a ca. 1-2 kg sample was taken for analysis. Samples were analyzed for chemical and physical properties by the Division of Agricultural and Natural Resources Analytical Laboratory at UC-Davis, according to their published protocols (http://danranlab.ucdavis.edu).

\section{Insect samples}

Samples of insects observed visiting flowers of wild tomatoes were collected for later identification. One individual of each bee species was trapped using a butterfly net, killed in 50\% ethanol, dried and stored in paper towels. Insects were identified to genus level by Prof. Lynn Kimsey at the Bohart Museum of Entomology, UC-Davis.

Plant trait measurements

Several plant characters affecting reproductive biology were measured on greenhouse grown samples of representative accessions of each species. Seed weight was measured in a sample of 100 dried seeds from each accession. Pollen diameter was measured as the equatorial diameter of pollen stained in $1 \%$ acetocarmine in $45 \%$ glacial acetic acid. Qualitative floral characters of the anthers and styles were assessed visually.

\section{Results and discussion}

Climate of the Atacama region

The germplasm collecting expeditions described herein focused on the northernmost three administrative regions of Chile, roughly from 18 to $26^{\circ} \mathrm{S}$ latitude, and from 68 to $71^{\circ} \mathrm{W}$ longitude (Fig. 1). The major geographic features are the Andes mountain chain and the coastal cordillera, separated by a central depression (valley). The few river drainages are broad valleys with mostly dry channels, and tributary branches reaching high into the Andes. This area includes the hyper arid Atacama Desert, extending approx between latitude $20-26^{\circ} \mathrm{S}$, and from the western crest of the Andes to the Pacific ocean. The Atacama Desert is arguably the oldest (150 million years, Hartley et al. 2005) and driest in the world, with average annual rainfall less than $10 \mathrm{~mm}$ (Houston 2006), and 'Mars-like' soils nearly devoid of life in some locations (NavarroGonzalez et al. 2003). This hyper-aridity results from several compounding physical factors, including subtropical anti-cyclonic atmospheric subsidence, cold water upwelling associated with the Humboldt Current, and the rain shadow effect of the Andes (Houston and Hartley 2003).

Rainfall along the coast is scant. For example, total annual precipitation at the cities of Arica and Iquique averages 0.9 and $1.5 \mathrm{~mm}$, respectively (Houston 2006), making them among the most arid cities in the world. During one 20 year period, Iquique received 'not one drop of water from the sky' for 14 of those years (Johnston 1929). Further south, at Taltal, annual rainfall is a little higher, ca. $11 \mathrm{~mm}$ per year (Johnston 1929). Persistent fog ('camanchaca') blankets the coastal mountains, in some areas supporting bands of vegetation, or fog-zone plant communities, called 'loma' formations (Rundel et al. 1991). In the central depression or valley region between the coastal and Andean cordilleras, rainfall is still very low-for example only $4.2 \mathrm{~mm}$ per year at Calama, elevation 2,260 m (Houston 2006). Progressing up the western slopes of the Andes, rainfall increases exponentially with elevation. From 2,000 to 5,000 m, precipitation can be estimated with the formula MAR $=\mathrm{e}^{0.0012 \mathrm{~A}}$, where MAR is the mean annual rainfall (in $\mathrm{mm}$ ) and $A$ is the altitude in meters (Houston 2002).

Rainfall in the Atacama region occurs primarily during the summer months of November-April, when storms extend from the east side of the Andes, a weather pattern known as the 'Bolivian Winter' (Houston 2006). For example, several sites within this region received over $90 \%$ of their annual precipitation in summer (Table 1). El Niño weather patterns (El Nino Southern Oscillation, or ENSO) produce relatively heavier rainfall along the coast, 
Fig. 1 Map of northern Chile showing geographic distribution of wild tomatoes and related Solanum species. The map shows all TGRC accessions, regardless of source (several plant collectors contributed material), collection date (a few were collected prior the period 1985-2005 referenced herein), or current distribution status (i.e., inactive or unavailable accessions are also shown)

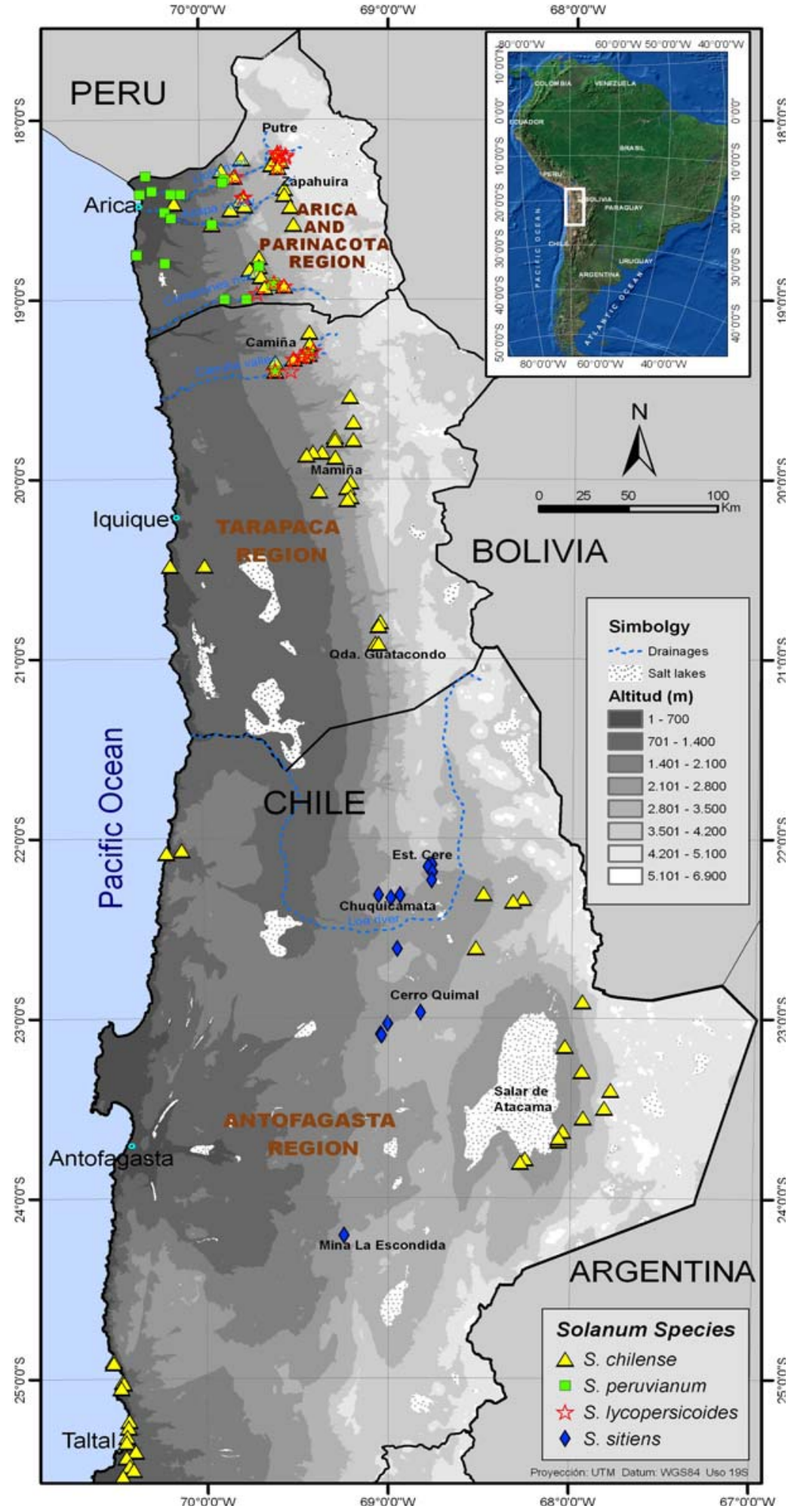


Table 1 Mean annual rainfall at various locations in northern Chile, and tomato species accessions collected at or near each site

\begin{tabular}{|c|c|c|c|c|c|c|c|}
\hline Location & Region & Latitude & Longitude & $\begin{array}{l}\text { Elevation } \\
(\text { m.a.s.1. })^{\mathrm{a}}\end{array}$ & $\begin{array}{l}\text { Mean annual } \\
\text { rainfall (mm) }\end{array}$ & $\begin{array}{l}\text { Fraction in summer } \\
(\text { NDJFMA })^{b}\end{array}$ & $\begin{array}{l}\text { Nearest species } \\
\text { and accessions }\end{array}$ \\
\hline Arica & $\begin{array}{l}\text { Arica- } \\
\text { parinacota }\end{array}$ & -18.50 & -70.27 & 5 & 0.9 & 0.49 & $\begin{array}{l}\text { S. peruvianum } \mathrm{LA} 4317^{\mathrm{c}} \\
\text { S. chilense LA } 2743\end{array}$ \\
\hline Camiña & Tarapacá & -19.32 & -69.42 & 2,380 & 13.4 & 0.95 & $\begin{array}{l}\text { S. chilense LA4124 } \\
\text { S. peruvianum LA4125 } \\
\text { S. lycopersicoides LA4123 }\end{array}$ \\
\hline Parca & Tarapacá & -20.02 & -69.20 & 2,570 & 27.3 & 0.91 & S. chilense LA2759 \\
\hline Guatacondo & Tarapacá & -20.93 & -69.05 & 2,460 & 11.5 & 0.86 & S. chilense LA2946 \\
\hline Caspana & Antofagasta & -22.32 & -68.22 & 3,260 & 63.3 & 0.90 & S. chilense LA4330 \\
\hline Chiu Chiu & Antofagasta & -22.33 & -68.65 & 2,524 & 4.4 & 0.65 & S. sitiens LA4113 \\
\hline Socaire & Antofagasta & -23.58 & -67.88 & 3,350 & 40.7 & 0.78 & S. chilense LA4119 \\
\hline Peine & Antofagasta & -23.68 & -68.07 & 2,480 & 18.1 & 0.74 & S. chilense LA2879 \\
\hline
\end{tabular}

Rainfall data are from Houston (2006) and are based on the 24-year period from 1977 to 2000

a Elevation of rain gauge station

${ }^{\text {b }} N$ November, $D$ December, etc.

c Collected from agricultural site, i.e., likely irrigated

however, torrential rains are virtually unknown along the north coast of Chile. For example, the maximum recorded rainfall for any $24 \mathrm{~h}$ period at Antofagasta, Iquique and Arica are 56, 13, and $10 \mathrm{~mm}$, respectively (Houston personal communication; Rundel et al. 1991). El Niño events tend to produce denser fogs and improved flowering conditions in the 'lomas' (Dillon and Rundel 1990). Such conditions benefit the wild tomatoes-for example, some $S$. chilense populations collected from the lomas are only present during El Niño years (R. Pinto and L. Faundez, personal communication). The contrasting weather pattern, La Niña, produces rainfall in the highlands only (Houston 2006).

Reflecting these climatic factors, as well as the physical features of the area, the plant communities of northern Chile can be divided into several major ecological zones (Thomann et al. 1987): below $4,000 \mathrm{~m}$ elevation, populations of wild tomatoes can be found in each of these zones (Table 2).

Table 2 The primary ecological zones of northern Chile in which wild tomatoes and related nightshades are found, and representative species and accessions from each

\begin{tabular}{lcl}
\hline Ecological zone & Elevation range $(\mathrm{m})$ & Native species and representative accessions $^{\mathrm{a}}$ \\
\hline Coastal & $0-300$ & S. chilense LA2750, LA2891, LA4107 \\
Lomas & $300-1,000$ & S. chilense LA2888, LA2932, LA2749, LA4339 \\
Valleys & $0-2,500$ & S. chilense LA4319, LA4132, LA2731 \\
& & S. peruvianum LA4317, LA4325, LA2732 \\
& & S. lycopersicoides LA4320, LA4131, LA2941 \\
Desert and/or pampas & $700-2,500$ & S. sitiens LA4113 \\
& & S. chilense LA2748, LA2879, \\
Pre-cordillera & $2,500-4,000$ & S. sitiens LA4105, LA2885, LA4331 \\
& & S. lycopersicoides LA4323, LA4123 \\
& & S. chilense LA4329, LA4122, LA4117A \\
\hline
\end{tabular}

Zones and elevation ranges are from Thomann et al. (1987)

${ }^{a}$ Partial list of accessions from each zone 
Soil salinity

Considering this general lack of rainfall, it's no surprise that soils in the Atacama Desert, particularly at lower elevations, tend to be saline. Our tests of soil samples taken from sites where wild tomatoes and related nightshades were collected confirmed this. A high level of salinity - indicated by electrical conductivity $>4 \mathrm{dS} / \mathrm{m}$ and elevated levels of $\mathrm{Na}^{+}, \mathrm{Cl}^{-}$and other ions-was found in many of these samples. The highest salt concentrations-up to $504 \mathrm{meq} / 1 \mathrm{Na}^{+}$, nearly equal to seawater-came from sites such as Sobraya ( $96 \mathrm{dS} / \mathrm{m}, 362 \mathrm{meq} / \mathrm{l} \mathrm{Na}^{+}$), Estacion Cere (65 dS/m, $504 \mathrm{meq} / \mathrm{l} \mathrm{Na}^{+}$), and Taltal $(27 \mathrm{dS} / \mathrm{m}$, $135 \mathrm{meq} / \mathrm{l} \mathrm{Na}^{+}$), where plants were growing in natural or artificial catchments or depressions that would capture occasional runoff and concentrate salts. For example, at the Cere site, $S$. sitiens (LA4113) plants were growing in basins-with evident salt encrustations-which would accumulate runoff from higher elevation (in this case, the Cerros de Paqui mountain). An adjacent dry salt lake bed provided striking evidence of salt accumulation (Fig. 2d). The Sobraya site (S. peruvianum LA2744) was in an agricultural area (Azapa Valley) irrigated by flooding basins with river water; this site also had the highest nitrate levels (629 ppm), perhaps due to residual fertilizer. The Catarata Taltal site (S. chilense LA4107) was within 100 meters of the Pacific ocean, and probably receives some salinity from ocean spray. The least saline sites were mostly from mid to high elevations in the Andes, where rainfall is more abundant.

To put these salinity levels into context, one can estimate their impact on yields of tomatoes grown under cultivation in similar soils, using the formula yield $=100-b \quad(\mathrm{EC}-a)$, where $a=$ threshold value above which yield declines $(a=2.5 \mathrm{dS} / \mathrm{m}$ for tomato), and $b=\%$ decrease in yield above the threshold ( $b=10 \%$ per $\mathrm{dS} / \mathrm{m}$ in tomato) (Hanson et al. 1999). Based on empirical data, this formula predicts that tomatoes grown at the Sobraya, Estacion Cere, or Catarata Taltal sites $(\mathrm{EC}=27.2-96)$ would result in zero yield of cultivated tomatoes.

The ions contributing the most to total salinity were sodium, calcium, chloride, nitrate and sulfate. Among the micronutrients, the levels of boron (up to $91 \mathrm{ppm}$ at Estacion Cere) were well above the level considered harmful to tomatoes (5.7 ppm, Hanson et al. 1999). Considering that the wild Solanum spp. collected at each of these saline sites were growing, flowering and fruiting in profusion, there can be little doubt that these species, in particular S. sitiens and $S$. chilense, possess a high level of tolerance to salinity.

Soils tended to be neutral to alkaline, and composed mostly of large particles (sand, $71 \%$ on average), with a smaller proportion of finer particles (silt $20 \%$, clay $8 \%$ ). These results are also consistent with expectations for desert soils, which tend to be alkaline, and derived from relatively unweathered mineral sources with a low organic content. This information is useful for optimizing soil mixes and watering regimes for greenhouse culture of these species (http://tgrc.ucdavis.edu/soils.html). Extremely sensitive to soil diseases brought on by overwatering, S. sitiens is best managed in the greenhouse by grafting onto tomato rootstocks (Chetelat and Petersen 2003).

Geographic distribution of the wild tomatoes and related Solanum species; Solanum chilense

The most widespread and common of the four tomato-related taxa in Chile, S. chilense extends from Taltal in the South, to Department of Arequipa in Peru (Fig. 1). The northernmost population within Chile appears to be near Estacion Puquio (LA4324), which is an arid, desolate, and inaccessible area near the border with Peru. Previously known only from an herbarium specimen (M. Ricardi 3527, CONC) collected in 1955 along the railroad tracks between Arica and $\mathrm{La} \mathrm{Paz}$, we found this population still growing at the same precise location 50 years later. The border region between Peru and Chile may contain other tomato populations, but has not been well explored because of its general inaccessibility and heavy military presence (including landmines, we were told). On the southern margin of the distribution, we collected a population of S. chilense at Quebrada los Zanjones (LA4339), about $15 \mathrm{~km}$ South of the Taltal populations, and in a different drainage system. This marginal population-also located from an herbarium specimen (M. Dillon 5495A)—represents the southern limit for $S$. chilense. Repeated searches, by us and other collectors, have failed to find wild tomatoes growing further south.

The elevational range of $S$. chilense is remarkably broad, extending from sea level (e.g., near Taltal) to over $3,500 \mathrm{~m}$. Our highest altitude collections were 

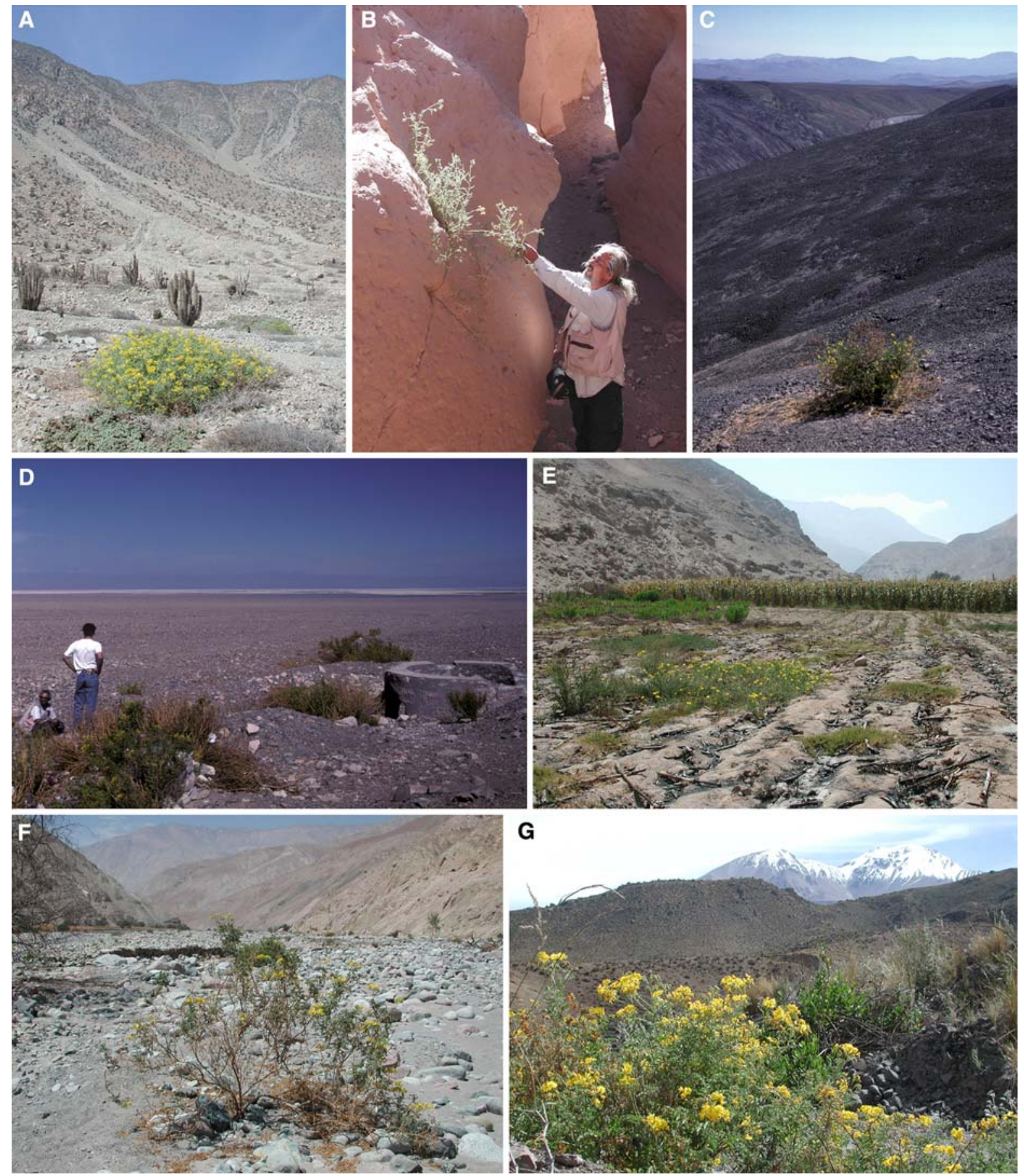

Fig. 2 Examples of the natural habitats of wild tomatoes and related nightshades in northern Chile. a, b $S$. chilense growing in the arid coastal zone (LA4336, Quebrada Cascabeles, elevation $54 \mathrm{~m}$ ), or in a narrow canyon located in the Andes (LA4333, Talabre, 2,914 m); c, d S. sitiens growing on an exposed, arid slope in the Cordillera de Domeyko (LA4105, Mina Escondida, 2,590 m) or in a shallow depression near a

dry salt flat (LA4114, Pampa Carbonatera, 2,750 m); e $S$. peruvianum growing as a weed in an abandoned agricultural field (LA4318, Sora-Molinos, 1,154 m); and f, g S. lycopersicoides growing in a dry riverbed (LA4320, Río Lluta, $1,490 \mathrm{~m}$ ) or on exposed slopes at high elevation in the Andes (LA4323, Putre, 3,600 m). Photos by C.M. Jones (a, b, e-g) and R. T. Chetelat (c, d) 
made in the vicinity of San Pedro de Atacama (LA4117A and B), which grow in a steep canyon below the Licancabur volcano, where it is exposed to cold air coming off the snow-covered slopes. Since S. chilense grows at least as high as any other sect. Lycopersicon species, including $S$. habrochaites (formerly L. hirsutum), and at lower latitudes than the others, it is potentially an excellent source of low temperature tolerance for tomato improvement (Wolf et al. 1986).

The San Pedro de Atacama population, and others collected around the Salar de Atacama, are morphologically distinctive: leaf segments are broad and glossy, petioles are shortened, and plants are more sensitive than usual to daylength, flowering only under short day conditions in our greenhouses at Davis. We also collected several new populations (LA4329, LA4330, LA4332) in the Andes between San Pedro de Atacama and Calama, in the drainage of the Río Salado, an area from which there were relatively few collections previously. These accessions 'link' the southern populations (Taltal, Atacama groups) to populations from the central part of the distribution, i.e., $\mathrm{N}$ of the Río Loa.

\section{Solanum peruvianum}

By comparison, S. peruvianum is much less widespread in Chile (Fig. 1), concentrated at lower elevations, and often growing in/near agricultural fields, where it sprouts within recently harvested or fallow fields (Fig. 2e). Weedy or feral populations of this type are found in the lower reaches of the Río Lluta (LA4317), Río Azapa (LA2744) and Río Camarones (LA4325) drainages. Within each of these valleys, large populations were found growing from sea level to mid elevations (up to $2,500 \mathrm{~m}$ ) in the river drainages. As expected for large populations of an obligate outcrosser, we observed much morphological variation from plant to plant, indicating a relatively high level of genetic diversity in this material. The coastal populations tended to be the largest and most diverse. Smaller populations were also found at mid elevations (up to 2,275 $\mathrm{m}$ ) in the upper Río Lluta and Río Camarones drainages (LA4318 and LA4328). The latter population, of which we could find only one plant, had a unique morphology - thick leathery leaves, with a glossy surface and highly dentate margins-suggesting it may represent a distinctive race of $S$. peruvianum. The southern limit for $S$. peruvianum appears to be the Río Camiña drainage (LA2732, LA4125), where it grows alongside both $S$. chilense (LA2952, LA4124) and S. lycopersicoides (LA4123).

\section{Solanum lycopersicoides}

The geographic distributions of $S$. lycopersicoides and $S$. sitiens are more limited than those of S. chilense or S. peruvianum. The present range of S. lycopersicoides extends from around Lago Aricota in southern Peru, to near the town of Camiña in northern Chile-plants have been reported further south, near Chusmisa but could not be confirmed (Faundez, personal communication). While the elevation range is broad, $1,200-3,700 \mathrm{~m}$, most populations occur at the higher altitudes (Fig. 1). The highest populations are those collected near Putre-at 3,700 m, the highest altitude of any of the tomato wild relatives. Only the $S$. chilense collected above San Pedro de Atacama (LA4117) comes close (note: some herbarium collections of $S$. chilense at higher elevations could not be confirmed on the ground). At the other extreme, two populations were collected from lower altitudes $(1,490$ and $1,290 \mathrm{~m}$ for LA4320 and LA4326, respectively) than any previous accessions of $S$. lycopersicoides. Only a few plants $(<8)$ were found at each location, suggesting they are marginally adapted.

The relatively wide altitudinal range of $S$. lycopersicoides may indicate this species was once more widespread than it is now. A threatened or endangered species, $S$. lycopersicoides is sensitive to disturbances such as farming and overgrazing. It's relative scarcity at low elevations may result from more intensive agriculture and other activities in the lower reaches of the drainages. We also collected the first accessions of $S$. lycopersicoides from the Río Camarones drainage, one of only three watersheds in N. Chile in which it has been found (the other two are Río Camiña, and Río Lluta/Putre). The populations from the Río Camiña drainage, first collected by Contreras and Thomann in 1988, are noteworthy for having produced more fertile hybrids with cultivated tomato than previously tested accessions, thus enabling the eventual introgression of a nearly complete nightshade genome into tomato (Canady et al. 2005). 


\section{Solanum sitiens}

The geographic range of $S$. sitiens is limited to a small part of the Atacama Desert, where it is scattered on slopes of the Cordillera de Domeyko and other secondary off-shoots of the Andes, in the area around Calama (Fig. 1). The range extends northward to around Cerro Paqui (LA4116) and East of Chuquicamata, and southward to the western slopes below Mina La Escondida (LA4105), also the westernmost population for this species. The altitudinal range for $S$. sitiens is relatively narrow, with most populations found at 2,500-3,000 m, although a few higher elevation sites (up to $3,500 \mathrm{~m}$ ) are recorded on herbarium specimens (Smith and Peralta 2002). The Escondida population is relatively isolated from the others, being separated by a distance of ca. $130 \mathrm{~km}$ from its closest neighbor at Mina San Juan (Fig. 1). Escondida is also morphologically distinctive, with broader and flatter leaves, and densely hairy shoots, suggesting it is a marginal population, perhaps a race or subspecies of $S$. sitiens. Recent tests of genetic relationships among these accessions using SSR markers also found Escondida to be highly differentiated from the others (Albrecht 2008).

\section{Ecology}

The wild tomatoes and related nightshades of northern Chile all show a strong tolerance to aridity, as might be expected from by the overall low rainfall of this region. Of the four taxa, S. sitiens is probably the most drought hardy, as it is found at more arid sites that the others, where it is sometimes the only perennial plant (Fig. 2c). Several xerophytic adaptations, some not shown by any other tomato relative, are evident in S. sitiens: (1) leaves are deeply incised, with narrow lamina, relatively small, and under extreme moisture deficit conditions, fold along the midvein, thereby reducing leaf surface area (Fig. 3i); (2) leaves are relatively thick and leathery, almost succulent (Fig. 3i), and surrounded by a thick epidermal cell layer and cuticle (not shown); (3) plants are able to sprout new shoots from the base of the stem or from the roots, allowing regeneration following a period of prolonged drought (Fig. 3f); and (4) fruit desiccate during maturation-rather than going through the ripening and softening process typical of most tomatoes-becoming a thin and
Fig. 3 Close-up photos of leaves, flowers and fruit, of a S. chilense (LA2767, Chitita), b S. peruvianum (LA2744, Sobraya); c leaves and flowers of S. lycopersicoides (LA4320, Río Lluta); d fruit of S. lycopersicoides (LA2772, Zapahuira); S. sitiens (LA4115, Cerro Paqui), with immature and mature, desiccated fruit; $\mathbf{f}$ base of unearthed $S$. sitiens plant showing new stems sprouting from below soil level; $\mathbf{g}$ rodent midden with partially eaten fruit of $S$. sitiens (note uneaten seeds); $\mathbf{h}$ flowers of S. sitiens (LA4113, Estacion Cere) grown in greenhouse; and i shoots of $S$. sitiens (LA2885, Caracoles), showing waxy leaves and fruit. Photos by C. M. Rick (a, b, d, f, g, i), C. M. Jones (c) and R. T. Chetelat $(\mathbf{e}, \mathbf{h})$

brittle shell, empty except for the loose the seeds within. The fruit eventually fall off the plant (Fig. 3e, i), roll downhill, or blow in the wind, thereby promoting seed dispersal in the dry desert environment. Piles of partially eaten fruit observed in rodent middens suggest that rats or mice also play a role as dispersal agents (Fig. 3g). In addition to these drought adaptations, S. sitiens also tolerates high levels of soil salinity, as explained above.

Also well adapted to drought stress, S. chilense thrives in exceedingly arid areas, including at low elevations along the coast, a region that receives the lowest annual precipitation. It is most often found in dry washes ('quebradas') (Fig. 2a) which channel moisture from rare rainfall events. In addition, S. chilense is sometimes found growing at the base of rock cliffs or within crevices in a rock face (Fig. 2b), suggesting it may exploit moisture condensing on the surface. In the coast ranges, $S$. chilense is relatively rare, being restricted to sites that receive more moisture, perhaps as runoff from rainfall or fog at higher elevations. This would include the loma formations where coastal fog accumulates and condenses (also reducing evapotranspiration), and, at least during El Niño years, some episodes of significant rainfall as well. Unlike the habitat of S. sitiens, which is nearly devoid of other perennial plants at most sites, S. chilense is often found in fairly rich plant communities. A tolerance of soil salinity is also indicated by observations of S. chilense at several locations. Among the most saline soils we sampled were from Sobraya and Catarata Taltal, both sites at which we found large populations. At some locations, such as Guatacondo (LA2931), S. chilense plants were found growing at the edge salt deposits several $\mathrm{cm}$ thick (C. M. Rick, personal communication).

Less drought hardy than these two species, $S$. lycopersicoides prefers cooler, somewhat more mesic 

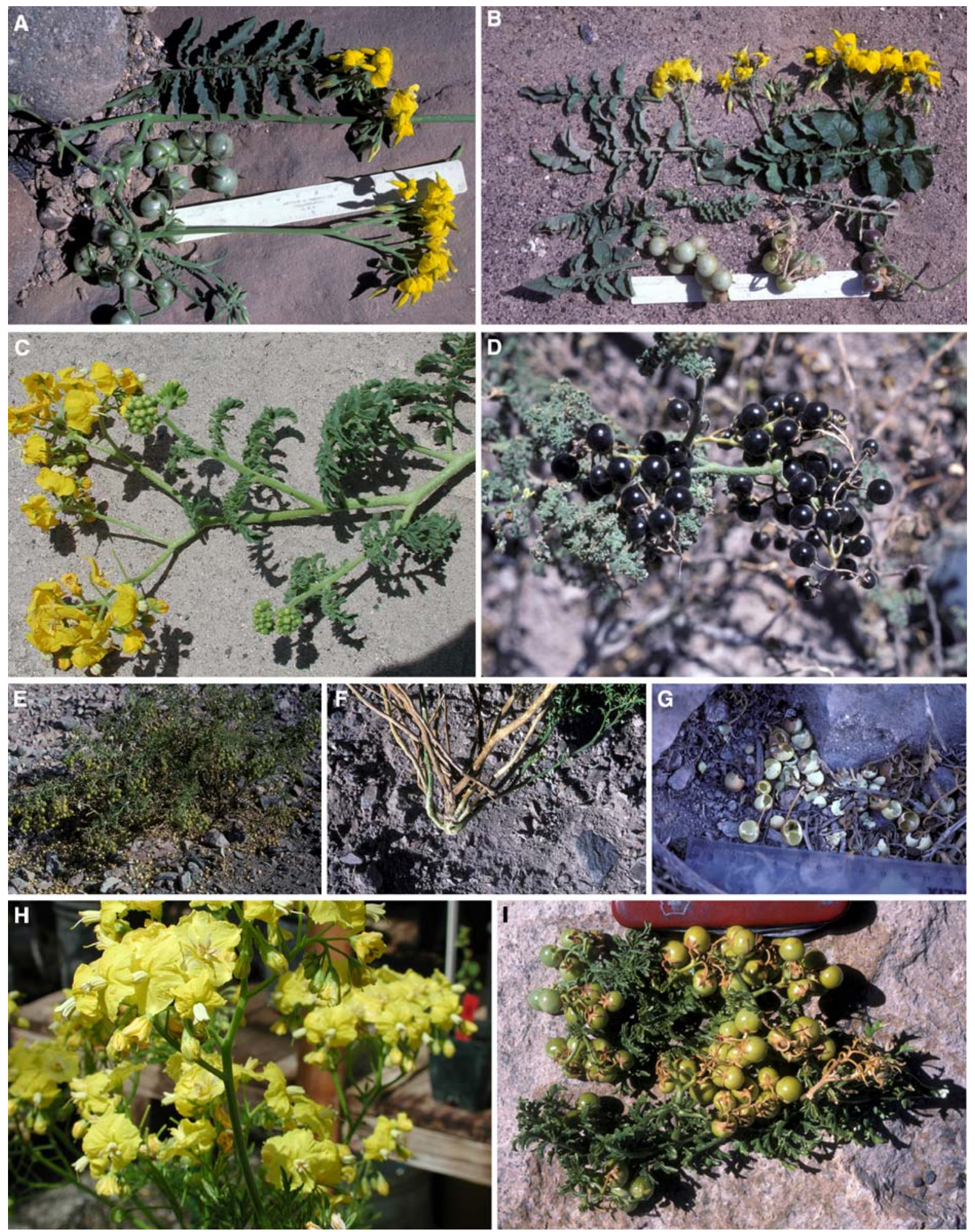
sites. It is found most often in steep river drainages, usually on the cooler south facing slopes, or in the river bottoms in the upper reaches of canyons (Fig. 2f). Growing at up to $3,700 \mathrm{~m}$, higher than any other tomato relative, $S$. lycopersicoides tolerates low temperatures, as has been confirmed by experimental studies (Wolf et al. 1986). In particular, the Putre population (LA2408, LA2781) is the highest of them all, and $S$. lycopersicoides plants there are growing in an exposed situation, subject to chilling and probably freezing conditions from cold air coming down off the nearby volcanoes (Fig. $2 \mathrm{~g}$ ). It is noteworthy that $S$. chilense is also found near Putre and elsewhere in the Río Lluta drainage, but it does not grow as high as $S$. lycopersicoides, suggesting the latter is more cold tolerant. A similar pattern is observed in the Río Camiña drainage.

In contrast to the preceding three species, all of which are found primarily on undisturbed sites, $S$. peruvianum is just the opposite, often growing in and around active agricultural fields. These tend to be in the lower sections of the river drainages, where there is more land area suitable for cultivation and water from irrigation or other sources is more abundant. The weediness of $S$. peruvianum may be due to its relatively high fecundity: based on our observations over many years at Davis, S. peruvianum flowers earlier and is less daylength sensitive than $S$. chilense, and its fruit contain, on average, more seeds (Table 3). In several river drainages, including the Lluta, Camarones, and Camiña, $S$. peruvianum can be found growing in proximity to either/both $S$. chilense and S. lycopersicoides. In each case, $S$. peruvianum is replaced by the other two taxa at high elevations (it grows up to about $2,500 \mathrm{~m}$ ), suggesting it is the least cold hardy. The generally broader leaves of $S$. peruvianum and its preference for agricultural fields also imply less drought tolerance than shown by the other species.

Pollination biology and mating systems

The four wild tomatoes and related nightshades of Chile are, with few exceptions, self-incompatible, and thus allogamous (obligate outcrossers). In the process of growing plants for seed regeneration at UC-Davis, we almost never observe spontaneous fruit set (i.e., without manual cross pollination), consistent with a strong SI response. Self-incompatibility in $S$. chilense is also revealed by abundant $S$-RNase alleles (Igic et al. 2007). Other traits that we generally observe in them, and that are consistent with an outcrossing mode of reproduction, are high levels of phenotypic variability (both within and between populations), large and brightly colored flowers, relatively elongated and highly divided inflorescences, and stigmas exserted several $\mathrm{mm}$ beyond the tip of the anther cone. So far, all accessions of S. chilense, S. lycopersicoides, and S. sitiens, and nearly all of $S$. peruvianum follow this pattern. On the other hand, one accession of $S$. peruvianum, collected from the Camiña area (LA4125), when grown at Davis, exhibited traits consistent with inbreeding: phenotypic uniformity, small, pale flowers, and spontaneous fruit set. Controlled pollinations (self and outcross) confirmed that this accession is selfcompatible (Graham et al. 2003). Interestingly, LA4125 was collected on the southern margins of the geographic distribution for $S$. peruvianum, suggesting SI may have been lost as a result of inbreeding associated with population bottlenecks and/or marginal adaptation. Similar changes in mating systems in marginal populations have been documented for S. habrochaites, S. pimpinellifolium, and S. pennellii (Rick et al. 1977, 1979; Rick and Tanksley 1981).

In the native environment, the SI populations depend on bees and possibly other insects for cross pollination services. To identify pollinators, we collected samples of any insects that were actively working flowers. At three locations, we observed bees on Solanum flowers. The first was near the coast, at Caleta Vitor, where S. peruvianum (LA4325) was growing as a weed in fallow agricultural fields. Here we found two species of bees actively buzzing flowers: a fairly small bee (length $5.7 \mathrm{~mm}$ ) identified as a species of Exomalopsis (family Apidae), and a larger species (length $17.4 \mathrm{~mm}$ ), identified as $\mathrm{Cau}$ policana (family Colletidae). The second site was in the Andes, near the town of Caspana $(3,100 \mathrm{~m})$, where we observed a relatively large (length $14.2 \mathrm{~mm}$ ) reddish-brown bee, identified as a species Centris spp. (family Apidae) on flowers of S. chilense (LA4330). The third site was also in the Andes, at Putre $(3,700 \mathrm{~m})$ where we observed-but could not trap-a black carpenter bee, Xylocopa spp. (family Apidae), on S. lycopersicoides (LA4323). No bees were seen visiting flowers of $S$. sitiens, but a large number of flies, probably a species of blowfly 


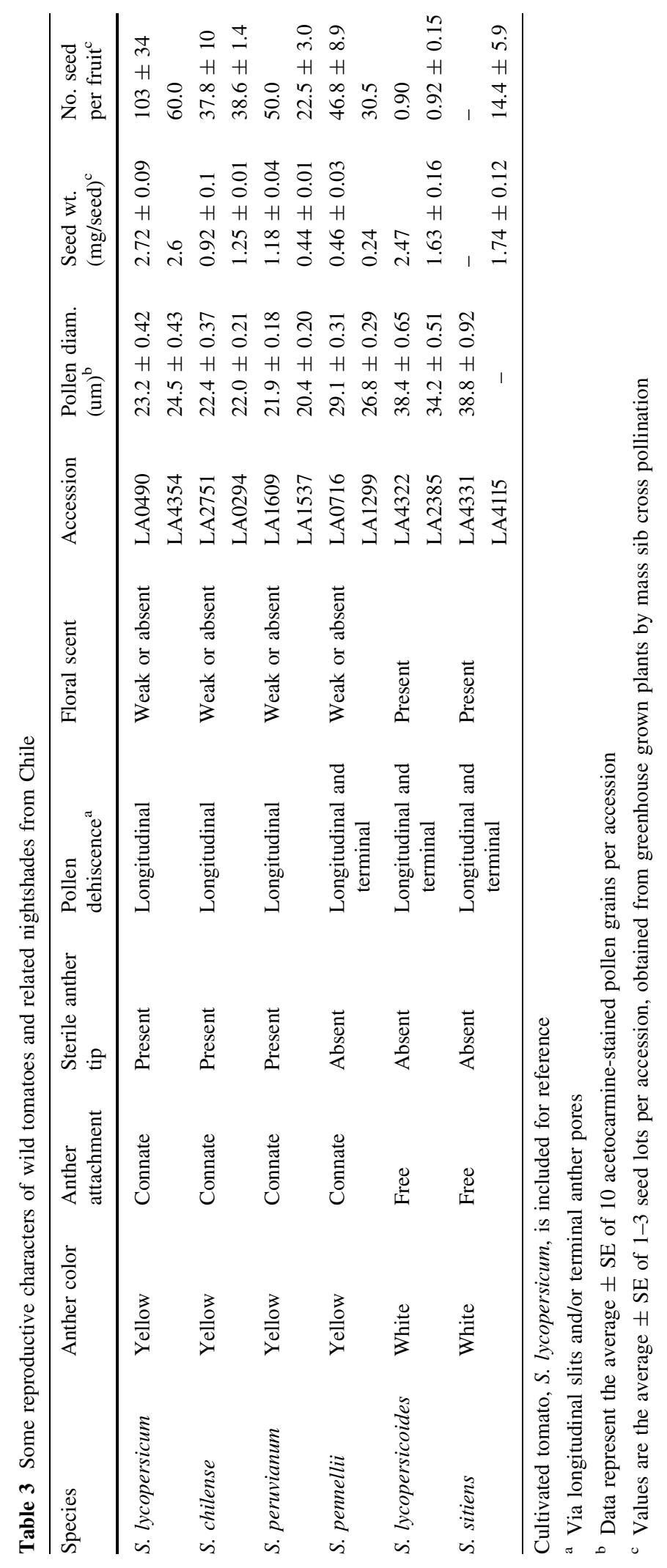


(Calliphoridae), were observed on flowers at one location, Estacion Cere (LA4113). The flies seemed more attracted to the corollas-flowers of this species are strongly scented-than the anthers, thus would seem unlikely to provide very effective pollination.

Some of the same bees (at least at the genus level) were previously reported to visit flowers of wild or cultivated tomatoes in Peru (Rick 1950; Rick et al. 1978). On flowers of $S$. pimpinellifolium and S. lycopersicum, Exomalopsis bruesii was responsible for at least $95 \%$ of the visits. On S. pimpinellifolium, Caupolicana vestita made occasional, short visits, and Centris surinamensis was seen on flowers of S. habrochaites. The Centris bee was only observed at high elevations $(2,000 \mathrm{~m}$ in this case), consistent with our observations in Chile. A total of 11 bee species in 6 families were identified by Rick (1950) on cultivated and wild tomatoes in Peru. On the Galapagos Islands, the endemic carpenter bee, Xylocopa darwinii - the only bee native to the islandswas observed on S. pimpinellifolium (Rick 1966). In Chile (Camiña area), Thomann et al. (1987) reported ants (Hymenoptera), flies (Diptera), and beetles (Coleoptera) on-but not necessarily pollinatingplants of S. chilense and/or S. peruvianum. Based on this diversity of potential pollinators, it seems likely that a more intensive search in Chile would turn up more than the three bee species found so far, especially considering that no likely pollen vectors have yet been identified on flowers of S. sitiens.

Several aspects of their flower morphology and biochemistry suggest that $S$. lycopersicoides and S. sitiens are less specialized for pollination by bees than the two tomato taxa. While all four species have entomophilous flowers, there are some striking differences between them. In the case of S. chilense and S. peruvianum, pollen is released via longitudinal slits into the inside of the anther cone, a trait conserved in all other sect. Lycopersicon spp. except $S$. pennellii (Table 3). Individual anthers are interlocked by hairs, and terminate in a sterile anther appendage (which is usually bent in $S$. peruvianum). Because of these structural features of the anthers, a vigorous vibration of the flowers is required to release pollen. Only some bees are equipped to perform such 'buzz' pollination, using their indirect flight muscles. In contrast, flowers of $S$. lycopersicoides and $S$. sitiens have unfused ('free') anthers, which open both at the tips and longitudinally, and lack a sterile anther appendage, all features that favor easier pollen shedding, even after relatively minor disturbance of the flowers. Thus wind, various insects (including, but perhaps not limited to, bees), or birds could conceivably play a role in pollen transfer for the two nightshades.

A further structural difference is seen in the pedicels and orientation of the flowers. In S. sitiens, pedicels are stiff and erect, and hold the flowers upright on the inflorescences (Fig. 3h). This might serve to enhance flower display and attractiveness to pollinators, or it could allow use of the flowers as a 'landing pad'. In contrast, flowers of the other species are more pendulous, with the anther cone horizontal or pointing downwards from the inflorescence (Fig. 3). This might indicate a greater specialization for bees, which hang below the anther cone to collect pollen. Thus, we speculate that flowers of S. sitiens may attract some unique pollinators not seen on the other species.

Another feature that seems consistent with a generalized mode of pollination in the two nightshades is their relatively high investment in male versus female gametes. Species adapted to abiotic (e.g., wind, gravity) or unspecialized biotic vectors often shed large volume of pollen and have a high pollen:ovule ratio (Frankel and Galun 1977). Flowers of S. lycopersicoides and $S$. sitiens release copious amounts of pollen-in our experience, much more than S. chilense or $S$. peruvianum - after only a gentle vibration of the inflorescence. In addition to these obvious differences in pollen yield, the two groups of species also differ with respect to pollen size (Table 3). The diameter of pollen from S. lycopersicoides or S. sitiens is $>60 \%$ greater than that of $S$. chilense or $S$. peruvianum (Table 3). In angiosperms, pollen grain size is positively correlated with style length: larger pollen can store more nutrients, supporting longer pollen tube growth (Lee 1978; Williams and Rouse 1990). Both S. lycopersicoides and S. sitiens have relatively long styles. Larger pollen grains may also promote more rapid germination and tube growth (Stanton and Preston 1985). Thus the large pollen of the nightshades suggests there is a high investment in, and strong competition among, male gametophytes. Further evidence in support of this hypothesis is that female gamete production is relatively limited in the nightshades: under conditions of artificial cross pollination in the greenhouse, an average fruit of $S$. lycopersicoides 
contains $<1$ seed (under natural conditions the value may be a little higher). In comparison fruit of S. chilense or S. peruvianum contain at least $20 \times$ more seed (Table 3). The limited number of available ovules per flower in S. lycopersicoides would theoretically create more of a fitness premium for competitive pollen (assuming flower number is more or less constant).

Alternatively, pollen size differences could be driven more by changes in flower structure related to evolution for bee (buzz) pollination. Pollen of S. pennellii are also larger (by ca. $30 \%$ ) than pollen of S. chilense or S. peruvianum (Table 3; Quiros 1975). Interestingly, S. pennellii is unique among the wild tomatoes in having terminal anther pores (Correll 1958), the key taxonomic character used previously to separate the Lycopersicon and Solanum genera (Rick 1960). We hypothesize that the smaller pollen of sect. Lycopersicon species could be an adaptation to lateral dehiscence (i.e., larger pollen might not be released effectively from a flower with fused anthers and a sterile tip).

Other differences between the two groups are seen in the size and shape of the stigma, bending of the style, color of the anthers, and scent production. Stigmas of $S$. lycopersicoides and $S$. sitiens are relatively broad, and subdivided into two major lobes extending to either side. This might facilitate pollen capture from more directions (i.e., from the sides as well as the distal end). Stigmas of $S$. chilense and $S$. peruvianum, on the other hand, are more narrow (only slightly wider than the style) and flat, which would seem to favor pollination from the end (e.g., from contact with a bee hanging off the flower) but not the sides. Styles of S. lycopersicoides and S. sitiens are often strongly recurved, sometimes pointing towards the base of the flower (Fig. 3c, h), whereas those of the tomato species are straight or slightly bent (Fig. 3a, b). Another striking difference is that flowers of $S$. sitiens and $S$. lycopersicoides are strongly scented, whereas those of $S$. chilense and $S$. peruvianum-like all other members of Solanum sect. Lycopersicon-have no obvious odor (Table 3 ). The production of volatile scent compounds presumably serves to attract insect pollinators, perhaps a broader suite of bee species or other types of insects. Interestingly, the floral scent of S. sitiens, a 'mothball-like' odor, is noticeably different from that of $S$. lycopersicoides, which is more reminiscent of honey or nectar.
The species also differ in the color of anthers: while $S$. peruvianum and $S$. chilense display the yellow anthers typical of all tomatoes, anthers of sect. Lycopersicoides are white to cream colored, a trait controlled by the dominant gene $W a$ (Rick et al. 1988). The flowers of $S$. lycopersicoides provide a strong contrast between the bright white anthers and deep yellow corollas, which may serve to distinguish its flowers from those of $S$. peruvianum and S. chilense, which are often found growing in close proximity. Anthers of $S$. sitiens are generally creamy white, less brilliant than anthers of $S$. lycopersicoides. Individual plants with yellow rather than white anthers can be found in both species: for S. lycopersicoides in the accession from Lago Aricota, Peru (LA4018), and for S. sitiens in the accession from Pampa Carbonatera (LA4114). Interestingly, these two accessions represent the northern geographic margins of their respective species. Thus, yellow color variants could be a sign of inbreeding (yellow is recessive to white in this case), as is sometimes seen on the margins of species distributions. Considering that white (or cream) colored anthers predominate, even in the segregating accessions, one can infer that there is strong selection on anther color, again suggesting pollinator specialization in the nightshades relative to the tomatoes.

\section{Conservation status and threat of genetic erosion}

The multiple expeditions to northern Chile described herein provided the opportunity to evaluate the status of populations collected previously, in light of habitat changes/loss, and assess risk of future impacts. For example, in 2005 we saw evidence of habitat destruction and loss of plants in the 4 years since the preceding trip. Most worrisome was a population of $S$. sitiens growing near Mina La Escondida (LA4105). This population is interesting because it represents the southernmost population for $S$. sitiens, is geographically isolated from the others (ca. $130 \mathrm{~km}$ from the closest known population, at Mina San Juan), and is morphologically distinctive. Analysis of genetic relationships with microsatellite markers also shows the Escondida population is genetically divergent from the other accessions (Albrecht 2008). This population grows on the slopes above the main road to two of the world's largest copper mines (Mina La Escondida and Mina 
Zaldivar). Since our 2001 visit, the road was enlarged to accommodate a pipeline, possibly damaging or destroying any plants that grew there, and creating more activity and disturbance over the fragile desert soils. On the other hand, at some localities, S. sitiens plants do well around pipelines, tanks, or other artificial sources of water. Marginal or precarious populations such as at Mina Escondida certainly deserve periodic monitoring.

In less arid zones, the principal threat to native vegetation comes from agriculture and overgrazing activities. Due to its preference for $\mathrm{S}$-facing slopes at high elevations, $S$. lycopersicoides is often found in areas subject to intense grazing. Although it is sometimes seen clinging to steep, rocky slopes inaccessible to large herbivores, certain aspects of its biology make this nightshade more vulnerable to grazing. It's seed output is so meager that we have trouble producing adequate seed even under optimal conditions in the greenhouse. Furthermore, seed require up to 6 months to mature, during which time fruit remain attached to the plant and are vulnerable to herbivory. Seed are also very large, which may make them less likely to survive chewing and digestion intact.

As the most widespread and common of the four species, $S$. chilense is arguably the least threatened, however, some populations are vulnerable. For example, we had collected in 2001 a small population (LA4107) alongside the coastal road just north of Taltal. This road has since been rebuilt and graded, with the result that it now bisects the $S$. chilense population. Such instances of habitat destruction seem likely to have an impact, at least locally, on population numbers. Populations from the coastal and lomas zones are perhaps most vulnerable, since they are relatively few and scattered to begin with, and rainfall is scarce or nonexistent in most years.

Unless conservation measures are implemented, the native tomatoes of Chile will almost certainly be increasingly impacted by human activities. Rising international prices and demand for copper will encourage further mining and associated economic development in the region. Human activities associated with mineral extraction/exploration, road building and other infrastructure development, grazing and agriculture, can all adversely impact the wild tomatoes and related nightshades. In light of these concerns, we recently submitted petitions and supporting materials to list $S$. lycopersicoides and
S. sitiens on Chile's IUCN 'Red List' of threatened or endangered species. Considering their potential economic value for tomato improvement, we suggest that a conservation plan is needed to protect these nightshades.

Acknowledgments The authors are deeply indebted to Andrés Contreras (University of Austral, Valdivia, Chile), Rudolf Thomann (formerly at Univ. de Tarapacá, Chile), Miguel Holle (CIP, Peru), and the late Charles M. Rick (UCDavis) for their thorough and timely collections of wild tomatoes in Chile-now maintained and distributed by the TGRC - as well as for sharing their notes and reports from these expeditions. We also gratefully acknowledge the assistance of John Houston (Nazca, S.A., Santiago) for providing rainfall data and helpful comments on the manuscript, Lynn Kimsey (UC-Davis) for identification of bee specimens, and Miguel Escobar for producing GIS maps. Jennifer Petersen and Katie Smith and their undergraduate student assistants grew plants for seed multiplication and observation at Davis. Roland Meyer (UC-Davis) helped interpret soil composition data. The following individuals generously provided access to herbarium records that helped us locate plants in the field: David Spooner (University of Wisconsin), Sandra Knapp (Natural History Museum, London), Iris Peralta (University of Cuyo, Argentina) Raquel Pinto (University of Iquique, Chile), Michael Dillon (The Field Museum, Chicago), and Mélica Muñoz-Schick (Museo Nacional de Historia Natural, Santiago). Funding for collecting expeditions was provided by grants from the USDA Plant Exchange Office (grants \#59-1275-5-350 and 59-1275-1-015 to R. Chételat and R. Pertuzé) and the International Board for Plant Genetic Resources (to C. M. Rick and A. Contreras).

Open Access This article is distributed under the terms of the Creative Commons Attribution Noncommercial License which permits any noncommercial use, distribution, and reproduction in any medium, provided the original author(s) and source are credited.

\section{References}

Albrecht E (2008) Comparative genetic linkage map for Solanum ochranthum and S. juglandifolium, and genetic diversity and population structure in S. lycopersicoides and $S$. sitiens. Ph.D. dissertation, University of Bonn, Germany

Canady MA, Meglic V, Chetelat RT (2005) A library of Solanum lycopersicoides introgression lines in cultivated tomato. Genome 48:607-685. doi:10.1139/g05-032

Chetelat RT, Petersen JP (2003) Improved maintenance of the tomato-like Solanum spp. by grafting. TGC 53:14-15

Chetelat RT, Cisneros P, Stamova L, Rick CM (1997) A malefertile Lycopersicon esculentum $\times$ Solanum lycopersicoides hybrid enables direct backcrossing to tomato at the diploid level. Euphytica 95:99-108. doi:10.1023/A:10029 58030799 
Correll DS (1958) A new species and some nomenclatural changes in Solanum, section Tuberarium. Madrono 14:232-238

Dillon MO, Rundel PW (1990) The botanical response of the Atacama and Peruvian Desert floras to the 1982-83 El Nino event. In: Glynn PW (ed) Global ecological consequences of the 1982-83 El Nino Southern Oscillation. Elsevier, Amsterdam, pp 487-504

Frankel R, Galun E (1977) Pollination mechanisms, reproduction and plant breeding. Springer, Berlin

Graham EB (2005) Genetic diversity and crossing relationships of Lycopersicon chilense. Ph.D. thesis, University of California, Davis

Graham EB, Shannon SM, Petersen JP, Chetelat RT (2003) A self-compatible population of Lycoperisicon peruvianum collected from N. Chile. TGC 53:22-24

Hanson B, Grattan SR, Fulton A (1999) Agricultural salinity and drainage. DANR publication no. 3375, University of California, Davis, 160pp

Hartley AJ, Chong G, Houston J, Mather AE (2005) 150 Million years of climatic stability: evidence from the Atacama Desert, northern Chile. J Geol Soc London 162:421-424. doi:10.1144/0016-764904-071

Houston J (2002) Groundwater recharge through an alluvial fan in the Atacama Desert, northern Chile: mechanisms, magnitudes and causes. Hydrol Process 16:3019-3035. doi:10.1002/hyp.1086

Houston J (2006) Variability of precipitation in the Atacama Desert: its causes and hydrological impact. Int J Climatol 26:2181-2198. doi:10.1002/joc.1359

Houston J, Hartley AJ (2003) The Central Andean west-slope rainshadow and its potential contribution to the origin of hyper-aridity in the Atacama Desert. Int J Climatol 23:1453-1464. doi:10.1002/joc.938

Igic B, Smith WA, Robertson KA, Schaal BA, Kohn JR (2007) Studies of self-incompatibility in wild tomatoes: I. S-Allele diversity in Solanum chilense Dun. (Solanaceae). Heredity 99:553-561. doi:10.1038/sj.hdy.6801035

Johnston IM (1929) Papers on the flora of northern Chile. Contribs Gray Herb 85:1

Lee S (1978) A factor analysis study of the functional significance of angiosperm pollen. Syst Bot 3:1-19

Navarro-Gonzalez R, Rainey FA, Molina P, Bagaley DR, Hollen BJ, de la Rosa J, Small AM, Quinn RC, Grunthaner FJ, Caceres L, Gomez-Silva B, McKay CP (2003) Mars-like soils in the Atacama Desert, Chile, and the dry limit of microbial life. Science 302:1018-1021. doi: 10.1126/science. 1089143

Peralta IE, Spooner DM, Knapp S (2008) Taxonomy of wild tomatoes and their relatives (Solanum sect. Lycopersicoides, sect. Juglandifolia, sect. Lycopersicon; Solanaceae). Syst Bot Monogr 84:1-186

Pertuze RA, Ji Y, Chetelat RT (2003) Transmission and recombination of homeologous Solanum sitiens chromosomes in tomato. Theor Appl Genet 107:1391-1401. doi: 10.1007/s00122-003-1384-Z

Quiros CF (1975) Exine pattern of a hybrid between Lycopersicon esculentum and Solanum pennellii. J Hered 66:45-47

Rick CM (1950) Pollination relations of Lycopersicon esculentum in native and foreign regions. Evol Int J Org Evol 4:110-122. doi:10.2307/2405388
Rick CM (1960) Hyridization between Lycopersicon esculentum and Solanum pennellii: phylogenetic and cytogenetic significance. Proc Natl Acad Sci USA 46:78-82. doi: 10.1073/pnas.46.1.78

Rick CM (1966) Some plant-animal relations on the Galapagos islands. In: Bowman RI (ed) The Galapagos. University of California Press, California, pp 215-224

Rick CM (1988) Tomato-like nightshades: affinities, autecology, and breeders opportunities. Econ Bot 42:145-154

Rick CM, Chetelat RT (1995) Utilization of related wild species for tomato improvement. Acta Hortic 412:21-38

Rick CM, Tanksley SD (1981) Genetic variation in Solanum pennellii: comparisons with two other sympatric tomato species. Plant Syst Evol 139:11-45. doi:10.1007/BF00983920

Rick CM, Fobes JF, Holle M (1977) Genetic variation in Lycopersicon pimpinellifolium: evidence of evolutionary change in mating systems. Plant Syst Evol 127:139-170. doi:10.1007/BF00984147

Rick CM, Holle M, Thorp RW (1978) Rates of cross-pollination in Lycopersicon pimpinellifolium: impact of genetic variation in floral characters. Plant Syst Evol 129:31-44. doi:10.1007/BF00988982

Rick CM, Fobes JF, Tanksley SD (1979) Evolution of mating systems in Lycopersicon hirsutum as deduced from genetic variation in electrophoretic and morphological characters. Plant Syst Evol 132:279-298. doi:10.1007/ BF00982390

Rick CM, Chetelat RT, DeVerna JW (1988) Recombination in sesquidiploid hybrids of Lycopersicon esculentum $\times$ Solanum lycopersicoides and derivatives. Theor Appl Genet 76:647-655. doi:10.1007/BF00303508

Rundel PW, Dillon MO, Palma B, Mooney HA, Gulmon SL, Ehleringer JR (1991) The phytogeography and ecology of the coastal Atacama and Peruvian Deserts. Aliso 13:1-49

Smith SD, Peralta IE (2002) Ecogeographic surveys as tools for analyzing potential reproductive isolating mechanisms: an example using Solanum juglandifolium Dunal, S. ochranthum Dunal, S. lycopersicoides Dunal, and $S$. sitiens I.M. Johnston. Taxon 51:341-349. doi:10.2307/ 1554931

Stanton ML, Preston RE (1985) Pollen allocation in wild radish: variation in pollen grain size and number. In: Mulcahy DL, Bergamini Mulcahy G, Ottaviano E (eds) Biotechnology and ecology of pollen. Springer, New York, pp 461-466

Thomann R, Contreras A, Rick CM, Holle M (1987) Recolleccion de recursos fitogeneticos en el Norte de Chile (Enfasis en Solanum spp., y Lycopersicon spp.); informe 1985-1987. Report to the International Board for Plant Genetic Resources

Williams EG, Rouse JL (1990) Relationships of pollen size, pistil length and pollen tube growth rates in Rhododendron and their influence on hybridization. Sex Plant Reprod 3:7-17. doi:10.1007/BF00189946

Wolf S, Yakir D, Stevens MA, Rudich J (1986) Cold temperature tolerance of wild tomato species. J Am Soc Hortic Sci 111:960-964

Zamir D (2001) Improving plant breeding with exotic genetic libraries. Natl Rev 2:983-989. doi:10.1038/35103589 